\title{
Camu-camu (Myrciaria dubia) from commercial cultivation has higher levels of bioactive compounds than native cultivation (Amazon Forest) and presents antimutagenic effects in vivo
}

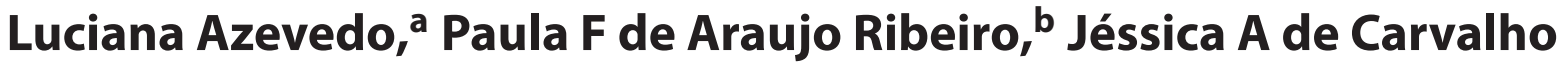

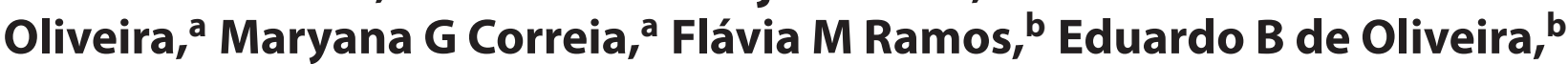 \\ Frederico Barros $^{b^{*}} \odot$ and Paulo C Stringheta ${ }^{b}$
}

\begin{abstract}
BACKGROUND: Camu-camu (Myrciaria dubia) is a typical Amazonian fruit and has high antioxidant capacity due to its high levels of vitamin $C$ and phenolic compounds. This study aimed to determine the phytochemicals, antioxidant capacity and antimutagenic effects of camu-camu fruits with different maturity stages grown in dry (commercial cultivation) or flooded environments (native cultivation, Amazon).

RESULTS: Total polyphenols, ascorbic acid and in vitro antioxidant capacity levels were higher in ripe fruits grown in a commercial cultivation. The extracts from ripe camu-camu grown in a commercial cultivation exerted antioxidant effects and high percentage of protection against doxorubicin and 1,2-dimethylhydrazine in all tested systems (liver, bone marrow and gut), for three camu-camu extract concentrations $\left(17,85\right.$ and $170 \mathrm{mg} \mathrm{kg}^{-1}$ body weight), as follows: bone marrow minocronucleus (37.91\%, 41.75\%, 43.95\%); micronucleus gut test (61.01\%, 64.40\%, 50.28\%); apoptosis index (60.26\%, 62.44\%, 58.22\%); comet assay through the tail moment $(71.64 \%, 72.31 \%, 70.70 \%)$, percent DNA in the tail $(64.54 \%, 68.75 \%, 76.79 \%)$ and tail intensity $(76.43 \%, 81.02 \%, 68.33 \%)$.
\end{abstract}

CONCLUSION: The results of this study contribute to increasing the production of camu-camu fruits grown in dry environments and their use as a health-promoting food.

(c) 2018 Society of Chemical Industry

Keywords: Myrciaria dubia; camu-camu; antimutagenic effects; phytochemicals

\section{INTRODUCTION}

The Amazon region is distinguished by its great biodiversity of fruits containing remarkable nutritional composition, therapeutic value, and thus agribusiness potential, such as guaraná (Paullinia cupana Kunth), castanha-do-brasil (Bertholletia excelsa Humb. \& Bonpl.), açaí (Euterpe oleracea Mart.), cupuaçu (Theobroma grandiflorum), araçá-pera (Psidium acutangulum) and pupunha (Bactris gasipaes Kunth). ${ }^{1-3}$ Among them, camu-camu (Myrciaria dubia) is a typical Amazonian fruit ${ }^{4}$ with natural occurrence during periods of flooding, near courses of rivers and lakes in the Amazon Forest. Camu-camu stands out above other plant species by its economic potential, being mainly exported by Peru in the form of flour (76\%), extract (13.4\%) and dehydrated (6.2\%). ${ }^{5}$ New ways of processing this fruit are being studied in order to serve an increased demand of its consumption as a functional ingredient for commercial use, with wide application such as in pharmaceutical manufacture, or in food processing, such as meat, bakery and dairy products. $^{4}$
Camu-camu has been under the spotlight because of its high antioxidant capacity, due to the chemical profile containing significant levels of vitamin $C$ and phenolic compounds such as ellagic acid and anthocyanins. ${ }^{6,7}$ As is well known, regular intake of foods containing antioxidants may prevent chronic diseases, such as inflammations, mutations, cancer and atherosclerosis..$^{8,9} \mathrm{All}$ these associated factors have created great interest in camu-camu production and, as consequence, commercial cultivation in dry environments has been increasing. However, the concentrations of

\footnotetext{
* Correspondence to: F Barros, Departamento de Tecnologia de Alimentos, Universidade Federal de Viçosa, Viçosa, Minas Gerais 36570-000, Brazil. E-mail: fredbarros@ufv.br

a Faculdade de Nutrição, Universidade Federal de Alfenas, Minas Gerais, Brazil

b Departamento de Tecnologia de Alimentos, Universidade Federal de Viçosa, Minas Gerais, Brazil
} 
these chemical compounds can vary within the fruit, depending on the environment (dry or flooded), where the fruit is grown, and also on its ripeness stage. ${ }^{10,11}$ In spite of the increase in applications of camu-camu from commercial cultivation as a functional food, there is still a lack of knowledge regarding its biological effects, such as antioxidant capacity and mutagenic/antimutagenic activity, when compared to fruits collected from flooded natural environments in the Amazon region.

In this study, we have chosen the micronucleus assay to detect mutagenic/antimutagenic activity, which is widely applicable to different cell types with potential for detection of both aneugen and clastogen damage. ${ }^{12}$ Although the micronucleus test is most frequently used to evaluate bone marrow, the gut micronucleus assay considers the gastrointestinal tract and its contact with food. Another important test applied for this purpose is the comet assay. This assay considers damage prior to the repair system when cells with increased DNA damage display increased DNA migration, resembling the image of a comet, indicating the amount of DNA breakage in the cell. ${ }^{13}$ All these assays are complementary and consist of an evaluation trial of the multi-endpoint assays in vivo. ${ }^{14}$

The objectives of this study were therefore to determine the chemical profile (e.g. levels of major phytochemicals and antioxidant capacity) of camu-camu fruits grown in different environments (dry and flooded), with different stages of ripeness, and to perform mutagenic/antimutagenic and antioxidant multi-endpoint in vivo assays in these fruits, in order to obtain more complete information about the health benefits of camu-camu.

\section{MATERIALS AND METHODS}

\section{Plant material and moisture content determination}

Fruits were collected in the Amazonas and Roraima states in the Brazilian Amazon Forest. Camu-camu from the Amazon, cultivated in dry conditions, was collected in the Yuricam Farm, located at km 100 of highway AM-010, in Rio Preto da Eva (latitude $2^{\circ} 41^{\prime} 56^{\prime \prime}$ $\mathrm{S}$, longitude $59^{\circ} 42^{\prime} 00^{\prime \prime} \mathrm{W}$ ). Camu-camu from Roraima, cultivated in a flooded environment, was collected from the margins of the middle Rio Branco, located $30 \mathrm{~km}$ north of Boa Vista (latitude $2^{\circ}$ $49^{\prime} 12^{\prime \prime} \mathrm{N}$, longitude $60^{\circ} 40^{\prime} 19^{\prime \prime} \mathrm{W}$ ) in April 2011. Both unripe and ripe fruits were collected from Amazonas (dry environment), characterized by their skin color: green in unripe fruit and red in ripe fruit. Only ripe fruits were collected from Roraima (flooded environment), because access was restricted by the flooding of the Amazon River, covering part of the camu-camu bushes for almost the entire period of fruit growth. Each experimental unit consisted of 10 randomly chosen fruits. For analyses performed with pitted fruits, the seeds were manually separated and the remainder (pulp and skin) was ground in a mixer (model Gourmet DMX433, Dellar, China). In another experiment, the skins were manually separated from the fruits and ground, using the same equipment.

The moisture level of the samples was determined by gravimetric drying at $105^{\circ} \mathrm{C}$ to constant weight. ${ }^{15}$

\section{Extraction and quantification of total polyphenols, anthocyanins and antioxidant capacity}

Crude extracts from the skin and pitted fruits of camu-camu were obtained by macerating $10 \mathrm{~g}$ of sample with $100 \mathrm{~mL}$ ethanol solution $\left(700 \mathrm{~mL} \mathrm{~L}^{-1}\right)$. The suspension was allowed to stand in the dark for $24 \mathrm{~h}$ under refrigeration $\left(7 \pm 1^{\circ} \mathrm{C}\right)$. The final extract $\mathrm{pH}$ was corrected to about 2.0.
The total polyphenol content was estimated using Folin-Ciocalteu reagent, according to spectrophotometric methodology. ${ }^{16}$ For accurate determination of the amount of polyphenols, samples were primarily eluted by Waters $C_{18}$ cartridge separation ${ }^{17}$ and the results were expressed as $\mathrm{mg}$ gallic acid equivalents (GAE) $100 \mathrm{~g}^{-1}$ dry weight. The content of total anthocyanins was determined by spectrophotometry, according to Lees and Francis. ${ }^{18}$ Readings were taken at $535 \mathrm{~nm}$ and the results were expressed as $\mathrm{mg}$ cyanidin 3-glucoside $100 \mathrm{~g}^{-1}$ pitted fruit or skin. Antioxidant capacity ( $\mu \mathrm{mol}$ Trolox equivalents $\mathrm{g}^{-1}$ sample) of the extracts was measured in vitro by 2,2'-azino-bis-3-ethylbenzthiazoline-6-sulfonic acid (ABTS) and 1,1-diphenyl-2-picrylhydrazyl (DPPH) assays as described by Phyu and Tangpong ${ }^{19}$ and Re et al. ${ }^{20}$

\section{Extraction and quantification of vitamin C (ascorbic acid), $\beta$-carotene, and free and total ellagic acid}

The extraction and quantification of vitamin $C$ in the skin and pitted fruits of camu-camu were performed according to Campos et al. ${ }^{21}$ The extraction of $\beta$-carotene from the skin and pitted fruits of camu-camu was performed according to Rodriguez et al. ${ }^{22}$ The identification and quantification of $\beta$-carotene in these samples were performed by high-performance liquid chromatography (HPLC) according to Pinheiro Sant'Ana et al. ${ }^{23}$ and results were expressed as $\mu \mathrm{g} 100 \mathrm{~g}^{-1}$ dry weight.

The extraction and quantification of free and total ellagic acid in the skin and pitted fruits of camu-camu were performed according Pinto et al., ${ }^{24}$ with modifications. Quantification of free ellagic acid (mg $100 \mathrm{~g}^{-1}$ dry weight) was performed by HPLC using a $4.0 \times 250 \mathrm{~mm}$ Dionex Acclaim $120 \mathrm{C}_{18}$ column $(5 \mu \mathrm{m})$ in reverse phase and UV-visible detector (Shimadzu SPD-10 AV), with detection at $254 \mathrm{~nm}$.

\section{Experimental design for the in vivo study}

Crude extracts from camu-camu fruits at optimum ripeness stage, from the Amazon region, were obtained according to the procedure described above and used in the in vivo study.

The animals used in this study were handled in accordance with the Ethical Principles for Animal Research adopted by the Brazilian College of Animal Experimentation (COBEA) with protocol approved by the University's Ethical Committee for animal research (23087.006783/2012-70). Male Swiss mice, 4-5 weeks old, weighing $19.1 \pm 1.5 \mathrm{~g}$, were divided into eight groups. The groups received the crude extracts of camu-camu in three concentrations based on their total polyphenol concentrations $(17,85$ and $170 \mathrm{mg} \mathrm{kg}^{-1}$ body weight (b.w.)) or water $\left(10 \mathrm{~mL} \mathrm{~kg}^{-1}\right.$ b.w.) by oral gavage twice a day, for 15 days. This dosage used in our study was based on studies carried out by Scalbert et al. ${ }^{25}$ and Scalbert and Williamson. ${ }^{26}$ They reported a total polyphenol intake of approximately $1 \mathrm{~g} \mathrm{~d}^{-1}$ for a person weighing about $60 \mathrm{~kg}$, corresponding to $17 \mathrm{mg} \mathrm{kg}^{-1}$ b.w. We therefore provided crude extracts with about $100 \%, 500 \%$ and $1000 \%$ total polyphenol intake by body weight. Before the end of the experiment (day 14), half of the animals from groups $1,2,3$ and 4 ( $n=8$ animals) received doxorubicin chloridate (DXR; Rubidox ${ }^{\circledR}$, Bergamo Laboratory, Italy; $\left.30 \mathrm{mg} \mathrm{kg}^{-1}\right)$, as a single i.p. dose, and the other half $(n=8$ animals) received oral gavage of 1,2-dimethylhydrazine dihydrochloride (DMH; Sigma, St Louis, MO, USA) $\left(30 \mathrm{mg} \mathrm{kg}^{-1}\right)$, both of them with a volume of $10 \mathrm{~mL} \mathrm{~kg}^{-1}$. Groups 5, 6, 7 and 8 ( $n=8$ animals in each group) received a physiological solution (PS; $\mathrm{NaCl} 0.9 \% \mathrm{w} / \mathrm{v}$ ). The animals that received DXR $(n=8)$ were used for the micronucleus (MN), comet and oxidative stress assays, and the other half 
( $n=8$ ) that received DMH were used for the gut micronucleus (MN) test and apoptosis assays. At the end of the study, all animals were anesthetized with ketamine and xylazine and then euthanized by exsanguination. At necropsy, the bone marrow cells, liver and colon were removed from the animals. The liver was perfused with PS and stored at $-80^{\circ} \mathrm{C}$. The colon was removed, opened longitudinally, fixed flat in buffered formalin for $24 \mathrm{~h}$, then placed in an ethanol solution $\left(700 \mathrm{~mL} \mathrm{~L}^{-1}\right)$.

\section{Bone marrow micronucleus, gut micronucleus and apoptosis assays}

These analyses were carried out for assaying the mutagenicity and antimutagenicity properties of camu-camu crude extracts. The bone marrow micronucleus test was conducted as originally described by MacGregor et al. ${ }^{27}$ Two thousand polychromatic erythrocytes (PCE) were analyzed per animal in slides blindly scored using a light microscope at $1000 \times$ magnification. For the gut micronucleus and apoptosis assays, colons were removed from the euthanized animals, washed with $0.9 \% \mathrm{NaCl}$ to remove fecal waste and cut longitudinally in the direction from the caecum to the anus. The gut micronucleus assay was performed according to Vanhauwaert et al., ${ }^{12}$ with some adjustments. For the staining procedure, the slides were first subjected to hydrolysis in $\mathrm{HCl}(5 \mathrm{~mol}$ $\mathrm{L}^{-1}$ ) for $15 \mathrm{~min}$ at room temperature, rinsed with distilled water three times, soaked in Schiff reagent (Merck, Germany) for 90 min, in the dark, then washed for 5 min in running water. After being washed, the slides were counterstained with Fast Green (Vetec Fine Chemicals LTDA, Brazil) $\left(5.0 \mathrm{mg} \mathrm{mL}^{-1}\right)$ for $30 \mathrm{~s}$ and rinsed in absolute ethanol. For each animal, 1000 colon epithelial cells were counted manually using a whole number of crypts in which a single continuous row of epithelium cells could be discerned from the proximal end adjacent to the muscle layer to the distal end at the mucosal surface analyzed in a light microscope at 1000× magnification. For analysis of apoptosis, the 'Swiss rolls' were stained with hematoxylin-eosin (HE). For the identification of apoptotic cells, a total of 20 perpendicular well-oriented crypts were examined in each animal, counting the total number of epithelial cells in each one. ${ }^{28}$ The apoptotic cells were identified as previously described by Risio et al. ${ }^{29}$ The apoptosis index (Al\%) was estimated as the percentage of apoptotic cells in relation to the total number of cells.

\section{Comet (single-cell gel electrophoresis assay) and oxidative stress assays}

The peripheral blood comet assay was executed as described in Azevedo et al., ${ }^{30}$ with some modifications. For this test, $7 \mu \mathrm{L}$ blood was mixed with $73 \mu \mathrm{L}$ low-melting-point agarose $\left(5.0 \mathrm{~mL} \mathrm{~L}^{-1}\right)$ to form a microgel. The slides were then immersed in lysis solution, and after $24 \mathrm{~h}$ the blades were placed in a horizontal tank of DNA gel electrophoresis and left to rest $(20 \mathrm{~min})$ in an alkaline solution $(\mathrm{pH} \geq 13.0)$. The fluorescent DNA marker (stained with Red Gel, 1:10000 dilution), was visualized using a fluorescence microscope with a magnification of $400 \times$ and with a green filter. Fifty cells were randomly counted from each blade and a total of 100 cells were counted in each animal; the resulting images were captured on a computer and processed by image analysis software (CometScore ${ }^{\mathrm{TM}}$ v. 1.5, TriTek freeware). The parameters for the analysis of DNA damage included: tail moment (TM), intensity of the tail (TI) and DNA content in the tail of the comet (percent of DNA in tail). For the oxidative stress assay mouse liver was used. Levels of the reduced (GSH) and oxidized (GSSG) forms of glutathione were determined using a method for a 96-well microtiter plate, as proposed by Rahman et al. ${ }^{31}$ and expressed as nmol mg ${ }^{-1}$ protein, using Bradford's method.

\section{Statistical analysis}

The experiment was conducted according to a completely randomized design (CRD) with three replications. Analysis of variance (ANOVA) and the Tukey average comparison test were applied to the chemical analysis data, and in vivo tests (growth performance and nutrient utilization, oxidative stress and comet assay). The $\chi^{2}$ test was used for comparison of micronucleus number. The statistical program used was SAS (Statistical Analysis System), version 9.2, licensed for UFV (Federal University of Viçosa, Brazil) in 2008. The results were considered statistically significant if $P$-values were 0.05 or less.

\section{RESULTS AND DISCUSSION \\ Chemical analyses}

A comprehensive evaluation of camu-camu from its native flooded environment and its dry cultivation, including the phytochemical profile, mutagenic and genotoxic activities, were provided in this study.

The fruits (ripe or unripe) grown in both environments (dry and flooded) exhibited the same content of pulp, skin and seed. They had, on average, $520 \mathrm{mg} \mathrm{g}^{-1}$ of pulp, $210 \mathrm{mg} \mathrm{g}^{-1}$ of skin and $260 \mathrm{mg} \mathrm{g}^{-1}$ of seed. The levels of total polyphenols were higher in the ripe fruits from dry environment $(14750 \mathrm{mg} \mathrm{GAE}$ $100 \mathrm{~g}^{-1}$ ) than in those from flooded environment (12 $217 \mathrm{mg} \mathrm{GAE}$ $100 \mathrm{~g}^{-1}$ ) (Table 1). The highest polyphenol content observed in this study was slightly lower than that observed by Genovese et al..$^{32}$ (17970 mg AGE $100 \mathrm{~g} \mathrm{~g}^{-1}$ dry weight) for fruits grown in a dry environment in the southwest of Brazil.

Thermal stress is one of the factors responsible for the increase of polyphenol levels in fruits. ${ }^{33}$ The lower concentration of polyphenols in the fruits grown in flooded cultivation (Table 1) may be in part because of the exposure to water when the level of Amazonian rivers is high, causing accumulation of water around the plant, which decreases its temperature. The levels of total polyphenols of camu-camu, regardless of the growing region, are far greater than the content reported for some fruits considered classical sources of these compounds, such as açai (Euterpe oleracea) and jabuticaba (Myrciaria jaboticaba) (3268 and 3584 mg GAE $100 \mathrm{~g}^{-1}$ dry weight, respectively). ${ }^{34}$

There were no differences in the total anthocyanin content between camu-camu fruits grown in dry or flooded environments (Table 1), despite their different climatic conditions (temperature, light and water) during fruit development and phenolic compounds formation. On the other hand, there were no anthocyanins in the unripe pitted fruits or skins (Table 1), which can be explained by the physiological changes during the maturation process. It is associated with an increased activity of chlorophyllase enzyme leading to chlorophyll degradation and enhanced accumulation of anthocyanins, turning the fruits red in the intermediate stage and purple at the end of maturation. ${ }^{35}$

Moreover, besides anthocyanins, it was also observed that the level of $\beta$-carotene was higher in the skins (Table 1 ), which shows the importance of consuming the whole camu-camu fruit. Levels of $\beta$-carotene found in the camu-camu fruits from dry environment $\left(197.22 \mu \mathrm{g} 100 \mathrm{~g}^{-1}\right.$, Table 1$)$ were slightly higher than the values found by Zanatta and Mercadante ${ }^{11}\left(73-142 \mu \mathrm{g} 100 \mathrm{~g}^{-1}\right.$, from São Paulo state). 
Table 1. Chemical analyses of pitted fruits and skins of camu-camu grown in different environments (amounts in $100 \mathrm{~g}$ of dry sample)

\begin{tabular}{|c|c|c|c|c|c|c|}
\hline \multirow[b]{2}{*}{ Determinations } & \multicolumn{4}{|c|}{ Cultivation in dry environment ${ }^{a}$} & \multicolumn{2}{|c|}{ Cultivation in flooded environment ${ }^{b}$} \\
\hline & $\begin{array}{c}\text { Ripe } \\
\text { pitted fruit }\end{array}$ & $\begin{array}{l}\text { Unripe } \\
\text { pitted fruit }\end{array}$ & Ripe skin & Unripe skin & $\begin{array}{c}\text { Ripe } \\
\text { pitted fruit }\end{array}$ & Ripe skin \\
\hline Moisture (\%) & $92.21 \pm 0.06 a$ & $92.3 \pm 0.24 a$ & $86.20 \pm 0.50 \mathrm{~b}$ & $86.20 \pm 0.51 b$ & $91.79 \pm 0.15 a$ & $86.70 \pm 0.08 b$ \\
\hline $\begin{array}{l}\text { Total polyphenols (mg GAE } \\
100 \mathrm{~g}^{-1} \text { ) }\end{array}$ & $14749.93 \pm 5.51 \mathrm{a}$ & $11252.75 \pm 180 d$ & $13348.97 \pm 99.94 b$ & $9889.79 \pm 101.19 f$ & $12216.84 \pm 85.02 c$ & $10611.08 \pm 130.36 \mathrm{e}$ \\
\hline Free ellagic acid (mg $100 \mathrm{~g}^{-1}$ ) & $17.75 \pm 1.57 c$ & $25.75 \pm 2.12 b$ & $18.13 \pm 1.06 c$ & $50.82 \pm 2.88 a$ & $27.50 \pm 3.54 b$ & $28.71 \pm 1.21 \mathrm{~b}$ \\
\hline Total ellagic acid (mg $100 \mathrm{~g}^{-1}$ ) & $425.44 \pm 23.47 b$ & $764.69 \pm 11.13 a$ & $472.80 \pm 30.96 b$ & $768.25 \pm 41.26 a$ & $348.31 \pm 40.22 b$ & $357.29 \pm 118.29 b$ \\
\hline $\begin{array}{l}\text { Total anthocyanins (mg } \\
\text { cyanidin-3-glucoside } 100 \mathrm{~g}^{-1} \text { ) }\end{array}$ & $209 \pm 5.02 \mathrm{ab}$ & ND & $223.14 \pm 6.89 a b$ & ND & $158.86 \pm 1.20 b$ & $171.87 \pm 5.37 a$ \\
\hline Vitamin C (mg $\left.100 \mathrm{~g}^{-1}\right)$ & $1100.54 \pm 18.7 a$ & $1022.65 \pm 47.9 a b$ & $1109.62 \pm 56.5 a$ & $1049.49 \pm 70 a, b$ & $945.70 \pm 23.3 b$ & $1003.88 \pm 79.4 a b$ \\
\hline$\beta$-Carotene $\left(\mu \mathrm{g} 100 \mathrm{~g}^{-1}\right)$ & $197.22 \pm 49.5 c$ & $282.48 \pm 63.4 c$ & $619.98 \pm 68.01 b$ & $981.15 \pm 80 a$ & $210.52 \pm 48.9 c$ & $569.23 \pm 80.2 b$ \\
\hline $\begin{array}{l}\text { ABTS }(\mu \mathrm{mol} \text { Trolox equivalents } \\
\left.\mathrm{g}^{-1}\right)\end{array}$ & $1418.25 \pm 17.65 a$ & $1058.54 \pm 21.53 c$ & $1370.64 \pm 30.36 a$ & $857.97 \pm 36.77 d$ & $1209.08 \pm 65.66 b$ & $997.07 \pm 16.44 c$ \\
\hline $\begin{array}{l}\text { DPPH ( } \mu \text { mol Trolox equivalents } \\
\mathrm{g}^{-1} \text { ) }\end{array}$ & $1520.45 \pm 112.79 a$ & $1066.50 \pm 38.20 c$ & $1328.50 \pm 14.40 \mathrm{~b}$ & $961.21 \pm 50.73 c$ & $1124.37 \pm 29.12 c$ & $978.64 \pm 10.93 c$ \\
\hline
\end{tabular}

The contents of free and total ellagic acid are presented in Table 1. Ripe fruits grown in a flooded environment had a higher proportion of free ellagic acid and, in consequence, lower content of its bonded form (e.g. ellagitannins or glycosylated). In addition, the total and free ellagic acid contents were greater in green fruits (pitted fruit and skin). The levels of either free $\left(17.75 \mathrm{mg} 100 \mathrm{~g}^{-1}\right.$ ) or total (425 mg $100 \mathrm{~g}^{-1}$ ) ellagic acid in the ripe pitted camu-camu fruit were higher than in the classical sources of these compounds, such as strawberry (Fragaria ananassa) (6-26 and 170-470 mg $100 \mathrm{~g}^{-1}$ dry weight, respectively). ${ }^{24}$ This ratio was similar to that in camu-camu cultivated in a dry environment (São Paulo state, Brazil), which presented a content of total ellagic acid of $480 \mathrm{mg}$ $100 \mathrm{~g}^{-1}$ (dry weight), while the free compound corresponds to only $3.3 \%$ of the total determined ( $16 \mathrm{mg} 100 \mathrm{~g}$ dry weight). ${ }^{32}$

The camu-camu fruit presented a high level of ascorbic acid, which was higher in the dry environment $\left(1100.54 \mathrm{mg}^{\left.100 \mathrm{~g}^{-1}\right)}\right.$ than in the flooded environment $\left(945.70 \mathrm{mg} 100 \mathrm{~g}^{-1}\right.$ ) (Table 1). Only $10 \mathrm{~g}$ camu-camu fruit would provide the daily recommended amount of ascorbic acid for an adult $(65-90 \mathrm{mg})^{36}$ and could be comparable and even higher than other fruits such as strawberries

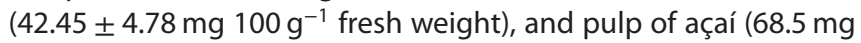
$100 \mathrm{~mL}^{-1}$ juice), ${ }^{37,38}$ highlighting their nutritional importance.

The high antioxidant capacity (DPPH and ABTS, Table 1) found in camu-camu fruits from both environments was also higher in the dry environment and ripe stage. The unripe camu-camu fruit is an important source of ellagic acid; however, its level was not high enough to increase the fruit antioxidant capacity significantly, perhaps influenced by its lower levels of anthocyanin and total polyphenols. Similar results were found by Rufino et al. ${ }^{34}$ and Genovese et al..$^{32}$ using camu-camu from the Brazilian states of Pará and São Paulo, respectively, which confirms that camu-camu retains its antioxidant potential even outside of its native region.

\section{In vivo study}

The camu-camu extracts were tested against the mutagenic effects of the drugs DXR and DMH in animals. The treatment groups with three concentrations of camu-camu did not display any genotoxic, mutagenic or oxidative stress effects in all performed assays when compared to their negative controls. In opposition, for all endpoints tested in these three kinds of systems - gut, bone marrow and blood-camu-camu exerted some level of protective effect against DXR (Table 2) or DMH (Table 3). These results highlight the protective potential of camu-camu extract as observed by the significant reduction of damage or increase of the repair system in the groups treated with camu-camu extract and DXR or DMH, when compared with respective positive control groups (G1: DXR or DMH only). These protective effects varied among assays and biological systems, but it was clear that the camu-camu extract exerted protection in all of them at some level, in the three extract concentrations $(17,85$ and $170 \mathrm{mg} \mathrm{kg}^{-1}$ ), as follows: bone marrow micronucleus $(37.91 \%$, 41.75\%, 43.95\%; Table 2); micronucleus gut test $(61.01 \%, 64.40 \%$, $50.28 \%$; Table 3); apoptosis index (60.26\%, 62.44\%, 58.22\%; Table 3); comet assay (Fig. 1) through the tail moment (71.64\%, $72.31 \%, 70.70 \%)$, percent DNA in the tail $(64.54 \%, 68.75 \%, 76.79 \%)$ and tail intensity $(76.43 \%, 81.02 \%, 68.33 \%)$.

These results indicate that camu-camu extracts have a protective effect in the first steps of mutation, protecting cells from primary DNA lesions (genotoxicity) such as strand breaks and/or alkali labile sites. This was concluded by the reduction in damage observed in the comet assay, which is based on the lysis of cells in microgels, electrophoresis and fluorescent staining of DNA. This technique detects primary DNA damage, before the repair system, nuclear division and conversion into mutations. ${ }^{39}$ Taking into account that the micronuclei are indicative of fixed chromosome breakage and/or chromosome loss (aneuploidy) passed onto progeny cells after complete nuclear division, the reduction of gut or bone marrow micronucleus frequencies may be due to the positive effects of the camu-camu extract compounds acting upon the DNA repair system. Our present observation agrees with many authors concerning the ability of phenolic compounds to stimulate DNA repair pathways, through transcription regulation or mRNA stabilization. ${ }^{40}$ Moreover, the reduction of the apoptosis level (Table 3 ) in the epithelial colon cells from the groups treated with camu-camu extract may have occurred as a result of the decrease of mutated cells. 
Table 2. The effects of different concentrations of camu-camu (Myrciaria dubia) in the frequencies of micronucleated polychromatic erythrocytes (MNPCE) in the bone marrow of mice

\begin{tabular}{|c|c|c|c|c|c|}
\hline Group / treatment & Cells & MNPCE & PCE/NCE & $\% \mathrm{MN}$ & $\% \mathrm{MN}$ reduction ${ }^{\mathrm{a}}$ \\
\hline G1 / positive control DXR & 16000 & 25.5 & $0.86 \pm 0.2$ & 0.16 & \\
\hline $\mathrm{G} 2$ / extract $17 \mathrm{mg} \mathrm{kg}^{-1}+\mathrm{DXR}$ & 16000 & 18.6 & $1.00 \pm 0.24$ & 0.12 & 37.91 \\
\hline $\mathrm{G} 3 /$ extract $85 \mathrm{mg} \mathrm{kg}^{-1}+\mathrm{DXR}$ & 16000 & 17.9 & $0.97 \pm 0.22$ & 0.11 & 41.75 \\
\hline $\mathrm{G} 4$ / extract $170 \mathrm{mg} \mathrm{kg}^{-1}+\mathrm{DXR}$ & 12000 & 17.5 & $0.88 \pm 0.13$ & 0.15 & 43.95 \\
\hline G5 / negative control PS & 16000 & 7.3 & $0.96 \pm 0.14$ & 0.05 & \\
\hline $\mathrm{G} 6 /$ extract $17 \mathrm{mg} \mathrm{kg}^{-1}+\mathrm{PS}$ & 16000 & 5.6 & $1.07 \pm 0.13$ & 0.04 & \\
\hline $\mathrm{G} 7 /$ extract $85 \mathrm{mg} \mathrm{kg}^{-1}+\mathrm{PS}$ & 14000 & 9.3 & $1.07 \pm 0.21$ & 0.07 & \\
\hline $\mathrm{G} 8 /$ extract $170 \mathrm{mg} \mathrm{kg}^{-1}+\mathrm{PS}$ & 16000 & 8.6 & $1.06 \pm 0.14$ & 0.05 & \\
\hline
\end{tabular}

DXR, doxorubicin (30 $\mathrm{mg} \mathrm{kg}^{-1}$ b.w.); PS, physiological solution ( $\mathrm{NaCl}, 0.9 \%$, w/v); extract, camu-camu (Myrciaria dubia), $17 \mathrm{mg} \mathrm{kg}^{-1} \mathrm{b.w}^{2}, 85 \mathrm{mg} \mathrm{kg}{ }^{-1}$ b.w., $170 \mathrm{mg} \mathrm{kg}^{-1}$ b.w.; PCE/NCE, polychromatic erythrocytes/normochromatic erythrocytes ratio; MNPCE, polychromatic erythrocytes micronucleus; $N=2000$ analyzed cells/animal.

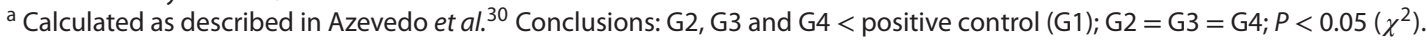

Table 3. Results of in vivo gut epithelial cells micronuclei test and apoptotic cells for different concentrations of extract of camu-camu (Myrciaria dubia)

\begin{tabular}{|c|c|c|c|c|c|c|c|c|}
\hline \multirow[b]{2}{*}{ Group / treatments } & \multicolumn{4}{|c|}{ Frequency of micronucleated gut epithelial cells } & \multicolumn{4}{|c|}{ Frequency of apoptotic cells } \\
\hline & Cell/ crypt & $\begin{array}{c}\text { Total } \\
\text { micronucleated } \\
\text { cells }\end{array}$ & $\% \mathrm{MN}$ & $\begin{array}{l}\% \mathrm{MN} \\
\text { reduction }^{\mathrm{a}}\end{array}$ & $\begin{array}{l}\text { Total } \\
\text { cells }\end{array}$ & $\begin{array}{c}\text { Total } \\
\text { apoptotic } \\
\text { cells }\end{array}$ & $\mathrm{Al} \%$ & $\begin{array}{c}\% \mathrm{Al} \\
\text { reduction }^{\mathrm{b}}\end{array}$ \\
\hline G1 / positive control DMH & 49.69 & 218 & 2.73 & & 1007.57 & 8.00 & 0.79 & \\
\hline $\mathrm{G} 2$ / extract $17 \mathrm{mg} \mathrm{kg}^{-1}+\mathrm{DMH}$ & 45.45 & 110 & 1.57 & 61.01 & 863.00 & 3.86 & 0.45 & 60.26 \\
\hline $\mathrm{G} 3$ / extract $85 \mathrm{mg} \mathrm{kg}^{-1}+\mathrm{DMH}$ & 42.94 & 104 & 1.49 & 64.40 & 851.29 & 3.71 & 0.44 & 62.44 \\
\hline $\mathrm{G} 4$ / extract $170 \mathrm{mg} \mathrm{kg}^{-1}+\mathrm{DMH}$ & 45.45 & 129 & 1.61 & 50.28 & 985.50 & 4.00 & 0.41 & 58.22 \\
\hline G5 / negative control PS & 48.78 & 41 & 0.51 & & 990.13 & 1.13 & 0.11 & \\
\hline $\mathrm{G} 6$ / extract $17 \mathrm{mg} \mathrm{kg}^{-1}+\mathrm{PS}$ & 46.24 & 35 & 0.44 & & 944.75 & 1.25 & 0.13 & \\
\hline $\mathrm{G} 7 /$ extract $85 \mathrm{mg} \mathrm{kg}^{-1}+\mathrm{PS}$ & 52.63 & 46 & 0.58 & & 885.13 & 1.50 & 0.17 & \\
\hline $\mathrm{G} 8$ / extract $170 \mathrm{mg} \mathrm{kg}^{-1}+\mathrm{PS}$ & 46.78 & 42 & 0.53 & & 906.38 & 0.88 & 0.10 & \\
\hline
\end{tabular}

The results demonstrate that the phytochemical compounds from camu-camu extract play a role in DMH and DXR metabolism, acting as a protective barrier against DNA damage induced by their carcinogenic intermediates. These results are related to a crude extract without purification that corresponds to a complex mixture of camu-camu polyphenols, which might exert synergistic effects in these antimutagenic effects. Moreover, the lack of a dose-dependent effect may be addressed by the matrix complexity of the Camu-camu crude extract and, consequently, its bioavailability and biological potential. Thus, regarding the colon protective effects against DMH damage, the extract compounds may act by reducing the availability of the active methyl diazonium ions generated by its metabolism in the liver, or increasing the repair activity of methylguanine methyltransferase protein (MGMT) under the formation of O6-MeG adducts. ${ }^{41}$ Additionally, the camu-camu phytochemicals could have acted against DXR mutagenicity via the following four different possibilities: (i) its activation and consequent decrease in the $\mathrm{OH}^{\bullet}$ free radicals and the lipid peroxidation produced; ${ }^{42}$ (ii) acting through stabilizing these free radicals generated, increasing the performance of endogenous antioxidants, ${ }^{43}$ (iii) decreasing the DXR inhibitory activity of the topoisomerase II enzyme; and finally (iv) preventing DNA lesions such as crosslinking, which leads to inter- and intra-strand DNA damage. ${ }^{44}$ This results in the accumulation of DNA strand breaks, which, unless they are repaired by the cell, cause mutations in in vivo and in vitro systems.

These antioxidant effects are confirmed by the parameter glutathione (GSH: tripeptide thiol, $\gamma$-glutamyl cysteinyl glycine) (Fig. 1), considered an indicator of oxidative stress, which exists in reduced sulfhydryl form (GSH) and its oxidized form, glutathione disulfide (GSSG). These structures take part in the enzymatic pathway of GSH peroxidase, which catalyzes the conversion of $\mathrm{H}_{2} \mathrm{O}_{2}$ to $\mathrm{H}_{2} \mathrm{O}$. ${ }^{31}$ Our results showed that the levels of GSH of groups treated with DXR plus camu-camu extract reached the same levels as the negative control. This means that the camu-camu phenolic extracts decreased oxidative stress by reducing the production of free radicals and consequently saving the reduced peptide (GSH). The formation of GSSG in the DXR group was higher (Fig. 1e), indicating that high levels of GSH were used and oxidized. Conversely, the higher dose of extract antagonized the DXR drug, leading towards the same level of GSSG as the 

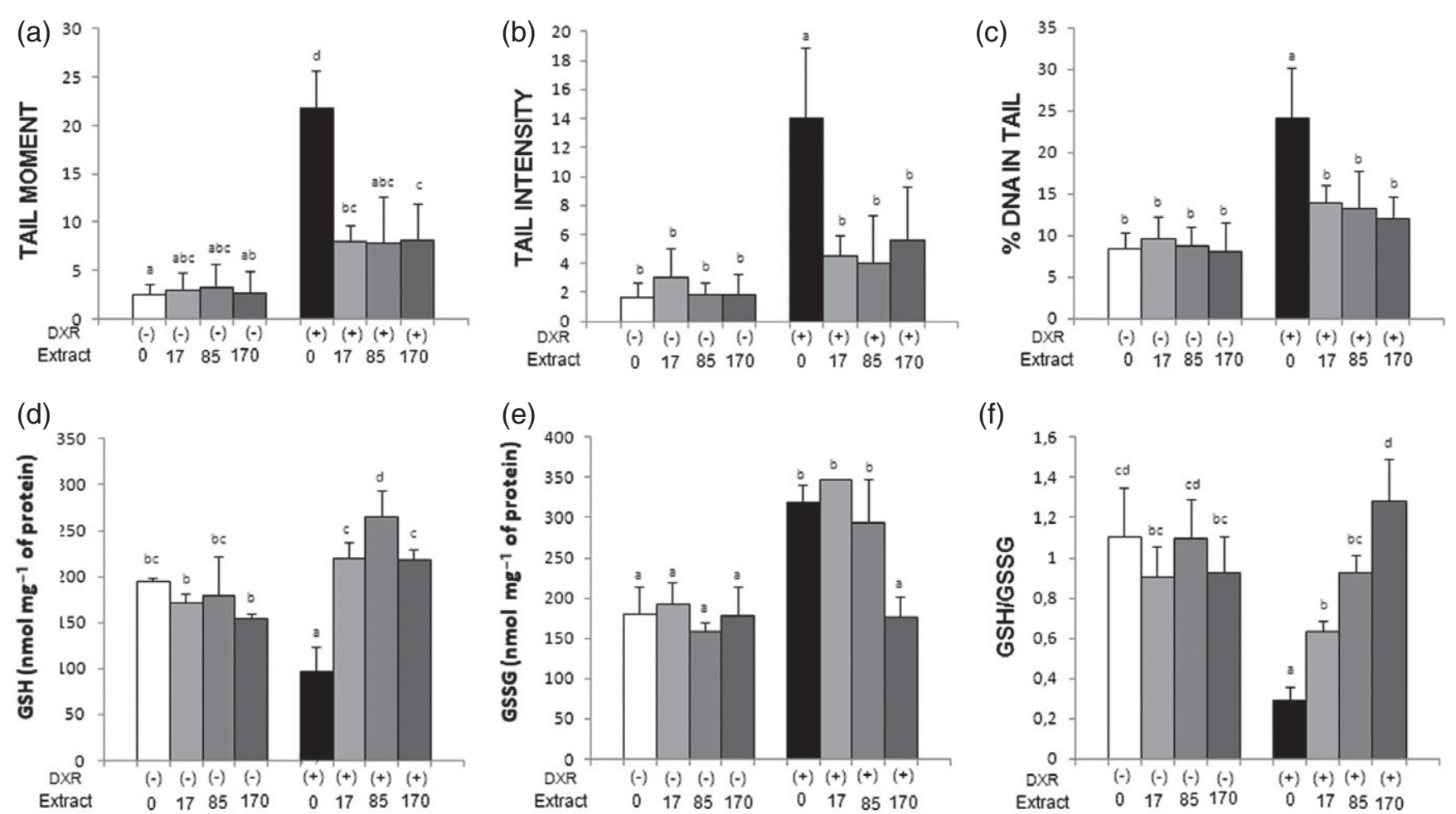

Figure 1. Results of in vivo comet assay and oxidative stress for different concentrations of camu-camu (Myrciaria dubia): (a-c) comet assay parameters; (d-f) glutathione levels ( $\mathrm{nmol} \mathrm{mg}^{-1}$ protein). GSH, glutathione reduced form; GSSG, glutathione disulfide form; DXR, doxorubicin (30 mg kg ${ }^{-1}$ b.w.); PS, physiological solution $(\mathrm{NaCl}, 0.9 \% \mathrm{w} / \mathrm{v})$; extracts $0,17,85$ and 170 mean the water and dosages of camu-camu extract $\left(\mathrm{mg} \mathrm{kg}^{-1} \mathrm{~b} . \mathrm{w}\right.$.) given to three animal groups by oral gavage. Quantitative data are the mean \pm standard deviation. Different letters within same parameter indicate a significant difference $(P<0.05$, Tukey test).

negative control (Fig. 1e). In addition, the ratio between these two cellular thiols (GSH/GSSG) is affected by oxidative stress, leading to its reduction in many organs of the body. ${ }^{31}$ In Fig. 1(f) it is possible to observe that this ratio gradually increased from the lowest level, in the positive control, to the highest level, in the highest concentration of camu-camu extracts. These results can be explained based on the positive relationship between the antioxidant capacity and total phenolic content, whose biological activity is based on its extent, nature, position of substituents, number of hydroxyl groups, complexation and their absorption capacity. ${ }^{45}$

Overall, the results of this study indicated that reactive oxygen species (ROS) scavenging plays a central role in the antigenotoxic and antimutagenic effects observed in the in vivo experiment, which can be attributed to the combination of phenolic compounds, carotenoids and vitamins from the complex mixtures of camu-camu crude extract. Silva et al. ${ }^{46}$ attributed to camu-camu antioxidants a fundamental role in the reduction of DNA damage assayed by the comet test, and associated this effect with the content of saponins, flavonoids and tannins, together with vitamin $\mathrm{C}$, by the following antioxidant mechanisms: chelation of metal and/or the elimination of free radicals, both of which can decrease oxygen toxicity to the cells and induction of antioxidant enzymes, triggered by the anthocyanin flavonoids present in this fruit. Moreover, there is clear evidence that radical scavenging activity depends on the polyphenol and substituents of the heterocyclic rings, which explains the ROS-quenching efficiency among different compounds. ${ }^{47}$ More specifically, ellagitannins, found at high levels in this study (total ellagic acid), were reported to exhibit stronger antioxidant activities, measured by both single-electron transfer assays and a hydrogen atom transfer assay, than gallic acid and ascorbic acid. $^{48}$

\section{CONCLUSION}

In this study, we have demonstrated that the camu-camu fruit is an important source of bioactive compounds, present at higher levels in fruits from a dry environment (commercial cultivation) compared to those from a flooded (Amazon Forest, Brazil) environment. This suggests that their commercial cultivation can be a feasible nutritional, functional and economic alternative. Moreover, camu-camu extracts decreased the in vivo oxidative stress and exerted protection against the mutagenic effects of the drugs on bone marrow and gut micronuclei, apoptosis and comet assay, which are able to predict the risk of cancer. These findings may provide new insights into the functional potential of camu-camu with beneficial effects on general health.

\section{ACKNOWLEDGEMENTS}

We gratefully acknowledge Fundação de Amparo à Pesquisa do Estado de Minas Gerais (FAPEMIG), Conselho Nacional de Desenvolvimento Científico e Tecnológico (CNPq) (483138/2013-4) and Coordenação de Aperfeiçoamento de Pessoal de Nível Superior (CAPES) for financial support.

\section{CONFLICT OF INTEREST}

The authors have no conflict of interest to declare. 


\section{REFERENCES}

1 Brandão ICD and Souza S. Amazônia é berço de frutas nativas de alto potencial comercial. [Online]. Portal Embrapa (2016). Available: https://www.embrapa.br/busca-de-noticias/-/noticia/14818376/ amazonia-e-berco-de-frutas-nativas-de-alto-potencial-comercial [25 May 2018].

2 Neri-Numa IA, Carvalho-Silva LB, Pinto J, Gomes L, Tiemi M, Emilson J etal., Evaluation of the antioxidant, antiproliferative and antimutagenic potential of araçá-boi fruit (Eugenia stipitata McVaugh - Myrtaceae ) of the Brazilian Amazon Forest. Food Res Int 50:70-76 (2013).

3 Ramos AS, Souza ROS, Paula A, Boleti DA, Bruginski ERD, Lima ES et al., Chemical characterization and antioxidant capacity of the araçá-pera (Psidium acutangulum): an exotic Amazon fruit. Food Res Int 75:315-327 (2015).

4 Fujita A, Souza VB, Daza LD, Favero-Trindade CS, Granato D and Genovese MI, Effects of spray-drying parameters on in vitro functional properties of Camu-Camu (Myrciaria dubia McVaugh): a typical Amazonian fruit. J Food Sci 82:1083-1091 (2017).

5 OTCA - Organização do Tratado de Cooperação Amazônica Exportaciones de camu-camu crecerían $79 \%$ en el presente año. [Online]. (2011). Available: www.otca.info/portal [1 January 2015].

6 Chirinos R, Galarza J, Betalleluz-Pallardel I, Pedreschi R and Campos D, Antioxidant compounds and antioxidant capacity of Peruvian camu (Myrciaria dubia (H.B.K.) McVaugh) fruit at different maturity stages. Food Chem 120:1019-1024 (2010).

7 Gonçalves AESS, Lajolo FM and Genovese MI, Chemical composition and antioxidant/antidiabetic potential of Brazilian native fruits and commercial frozen pulps. J Agric Food Chem 58:4666-4674 (2010).

8 Hooper $L$ and Cassid A, A review of the health care potential of bioactive compounds. J Sci Food Agric 86:1805-1813 (2006).

9 Pistollato F, Giampieri $F$ and Battino $M$, The use of plant-derived bioactive compounds to target cancer stem cells and modulate tumor microenvironment. Food Chem Toxicol 75:58-70 (2015).

10 da Silva Nunes $R$, Kahl VFS, da Silva Sarmento M, Richter MF, Costa-Lotufo LV, Rodrigues FAR et al., Antigenotoxicity and antioxidant activity of Acerola fruit (Malpighia glabra L.) at two stages of ripeness. Plant Foods Human Nutr 66:129-135 (2011).

11 Zanatta CF and Mercadante AZ, Carotenoid composition from the Brazilian tropical fruit camu-camu (Myrciaria dubia). Food Chem 101:1526-1532 (2007).

12 Vanhauwaert $A$, Vanparys $P$ and Kirsch-Volders $M$, The in vivo gut micronucleus test detects clastogens and aneugens given by gavage. Mutagenesis 16:39-50 (2001).

13 Singh NP, McCoy MT, Tice RR and Schneider EL, A simple technique for quantitation of low levels of DNA damage in individual cells. Exp Cell Res 175:184-191 (1988).

14 Bowen DE, Whitwell JH, Lillford L, Henderson D, Kidd D, Mc Garry $S$ et al., Evaluation of a multi-endpoint assay in rats, combining the bone-marrow micronucleus test, the Comet assay and the flow-cytometric peripheral blood micronucleus test. Mutat Res Genet Toxicol Environ Mutagen 722:7-19 (2011).

15 AOAC, Official Methods of Analysis of the AOAC, 8th edn. AOAC International, Gaithersburg, MD (2005).

16 Singleton VL and Rossi JA, Colorimetry of total phenolics with phosphomolybdic-phosphotungstic acid reagents. Am J Enol Vitic 16:144-158 (1965).

17 Noratto GD, Bertoldi MC, Krenek K, Talcott ST, Stringheta PC and Mertens-Talcott SU, Anticarcinogenic effects of polyphenolics from mango (Mangifera indica) varieties. J Agric Food Chem 58:4104-4112 (2010).

18 Lees $\mathrm{DH}$ and Francis $\mathrm{GH}$, Standardization of pigment analysis in cranberries. Hortic Sci 7:83-84 (1972).

19 Phyu MP and Tangpong J, Neuroprotective effects of xanthone derivative of Garcinia mangostana against lead-induced acetylcholinesterase dysfunction and cognitive impairment. Food Chem Toxicol 70:151 - 156 (2014).

20 Re R, Pellegrini N, Proteggente A, Pannala A, Yang M and Rice-Evans C, Antioxidant activity applying an improved ABTS radical cation decolorization assay. Free Radic Biol Med 26:1231-1237 (1999).

21 Campos FM, Ribeiro SMR, Della Lucia CM, Pinheiro-Sant'Ana HM and Stringheta PC, Optimization of methodology to analyze ascorbic and dehydroascorbic acid in vegetables. Quim Nova 32:87-91 (2009).

22 Rodriguez DB, Raymundo LC, Tung-Ching LE, Simpson KL and Chichester CO, Carotenoid pigment changes in ripening Momordica charantia fruits. Ann Bot 40:615-624 (1976).
23 Pinheiro-Sant'Ana HM, Stringheta PC, Cardoso Brandão SC and Cordeiro De Azeredo RM, Carotenoid retention and vitamin A value in carrot (Daucus carota L.) prepared by food service. Food Chem 61:145-151 (1998).

24 Pinto MS, Lajolo FM and Genovese MI, Bioactive compounds and quantification of total ellagic acid in strawberries (Fragaria $\times$ ananassa Duch.). Food Chem 107:1629-1635 (2008).

25 Scalbert A, Johnson IT and Saltmarsh M, Polyphenols: antioxidants and beyond. Am J Clin Nutr 81:215S-217S (2005).

26 Scalbert A and Williamson G, Dietary intake and bioavailability of polyphenols. J Nutr 130:2073S-2085S (2000).

27 MacGregor JT, Heddle JA, Hite M, Margolin BH, Ramel C, Salamone MF et al., Guidelines for the conduct of micronucleus assays in mammalian bone marrow erythrocytes. Mutat Res 189:103-112 (1987).

28 Chang WL, Chapkin RS and Lupton JR, Predictive value of proliferation, differentiation and apoptosis as intermediate markers for colon tumorigenesis. Carcinogenesis 18:721-730 (1997).

29 Risio M, Lipkin M, Newmark H, Risio M, Lipkin M, Newmark H et al., Apoptosis, cell replication, and western-style diet-induced tumorigenesis in the mouse colon. Cancer Res 56:4910-4916 (1996).

30 Azevedo L, Gomes JC, Stringheta PC, Gontijo ÁMMC, Padovani CR, Ribeiro LR et al., Black bean (Phaseolus vulgaris L.) as a protective agent against DNA damage in mice. Food Chem Toxicol 41:1671-1676 (2003).

31 Rahman I, Kode A and Biswas SK, Assay for quantitative determination of glutathione and glutathione disulfide levels using enzymatic recycling method. Nat Protoc 1:3159-3165 (2006).

32 Genovese MI, Pinto MS, Goncalves AESS and Lajolo FM, Bioactive compounds and antioxidant capacity of exotic fruits and commercial frozen pulps from Brazil. Food Sci Technol Int 14:207-214 (2008).

33 Naczk M and Shahidi F, Extraction and analysis of phenolics in food. $J$ Chromatogr A 1054:95-111 (2004).

34 Rufino MDSM, Alves RE, de Brito ES, Pérez-Jiménez J, Saura-Calixto F and Mancini-Filho J, Bioactive compounds and antioxidant capacities of 18 non-traditional tropical fruits from Brazil. Food Chem 121:996-1002 (2010).

35 Singh SP, Saini MK, Singh J and Pongener AGS, Preharvest application of abscisic acid promotes anthocyanins accumulation in pericarp of litchi fruit without adversely affecting postharvest quality. Postharvest Biol Technol 96:14-22 (2014).

36 IOM - Institute of Medicine, Food and Nutrition Board, Dietary Reference Intakes for Vitamin C, Vitamin E, Selenium, and Carotenoids. National Academy Press, Washington, DC (2000).

37 Cardoso PC, Tomazini APB, Stringheta PC, Ribeiro SMR and Pinheiro-Sant'Ana HM, Vitamin $C$ and carotenoids in organic and conventional fruits grown in Brazil. Food Chem 126:411-416 (2011).

38 Neves LC, Tosin JM, Benedette RM and Cisneros-Zevallos L, Post-harvest nutraceutical behaviour during ripening and senescence of 8 highly perishable fruit species from the Northern Brazilian Amazon region. Food Chem 174:188-196 (2015).

39 Kirsch-Volders M, Plas G, Elhajouji A, Lukamowicz M, Gonzalez L, Vande Loock $\mathrm{K}$ et al., The in vitro MN assay in 2011: origin and fate, biological significance, protocols, high throughput methodologies and toxicological relevance. Arch Toxicol 85:873-899 (2011).

40 Abalea V, Cillard J, Dubos MP, Sergent O, Cillard P and Morel I, Repair of iron-induced DNA oxidation by the flavonoid myricetin in primary rat hepatocyte cultures. Free Radic Biol Med 26:1457-1466 (1999).

41 Newell LE and Heddle JA, The potent colon carcinogen, 1,2-dimethylhydrazine induces mutations primarily in the colon. Mutat Res Genet Toxicol Environ Mutagen 564:1 - 7 (2004).

42 Venkatesh P, Shantala B, Jagetia GC, Rao KK and Baliga MS, Modulation of doxorubicin-induced genotoxicity by Aegle marmelos in mouse bone marrow: a micronucleus study. Integr Cancer Ther 6:42-53 (2007).

43 da Silva FC, Arruda A, Ledel A, Dauth C, Romão NF, Viana RN et al., Antigenotoxic effect of acute, subacute and chronic treatments with Amazonian camu-camu (Myrciaria dubia) juice on mice blood cells. Food Chem Toxicol 50:2275-2281 (2012).

44 Yadav L, Khan S, Shekh K and Jena GB, Influence of 3-aminobenzamide, an inhibitor of poly (ADP-ribose)polymerase, in the evaluation of 
the genotoxicity of doxorubicin, cyclophosphamide and zidovudine in female mice. Mutat Res Genet Toxicol Environ Mutagen 770:6-15 (2014).

45 Valko $\mathrm{M}$, Rhodes $\mathrm{CJ}$, Moncol J, Izakovic $\mathrm{M}$ and Mazur M, Free radicals, metals and antioxidants in oxidative stress-induced cancer. Chem Biol Interact 160:1 -40 (2006).

46 Silva FC, Arruda A, Ledel A, Dauth C, Romão NF, Viana RN et al., Antigenotoxic effect of acute, subacute and chronic treatments with
Amazonian camu-camu (Myrciaria dubia) juice on mice blood cells. Food Chem Toxicol 50:2275-2281 (2012).

47 Cemeli E, Baumgartner A and Anderson D, Antioxidants and the Comet assay. Mutat Res 681:51-67 (2009).

48 Kaneshima T, Myoda T, Nakata M, Fujimori T and Toeda K, Antioxidant activity of C-glycosidic ellagitannins from the seeds and peel of camu-camu (Myrciaria dubia). LWT - Food Sci Technol 69:76-81 (2016). 